\title{
The Influence of Tax Authority on Corporate Tax Avoidance: Mechanism and Motivation
}

\author{
Jiameng Ma Sujia Guo \\ School of Management, Shanghai University Shanghai 200000, China
}

\begin{abstract}
In the past, literature about the government's influence on corporate tax burden have studied corporate tax avoidance from the perspective of tax collection and management, while few have examined corporate tax avoidance from the perspective of policy formulation and policymakers. This paper fills this gap. Government is an empty concept, and its policy characteristics are actually the reflection of real core government officials' decision- making. By referring to Bertrand and Schoar (2003), Dyreng, Hanlon, and Maydew (2008), this paper finds that individual factors of financial leadership have a significant impact on the level of income tax rates of companies in their jurisdictions. Furthermore, the formulation of the financial budget is the influence path, including the proportion of local general budget revenue in local GDP, the proportion of local general budget expenditure in local GDP, the proportion of local tax revenue in local GDP, and the proportion of local enterprise income tax in all tax revenue. Finally, this paper finds that the leaders' motivation for their future careers is the influence of corporate tax avoidance. The characteristics that impact corporate income tax are the tenure of the director of finance, age, and whether the next post is promoted to the vice governor or vice mayor.
\end{abstract}

Keywords: treasurer; corporate tax avoidance; individual characteristics

About the Author: Ma Jiameng (1989-), female, a Shanghai native, doctor, lecturer, School of Management, Shanghai University, engaged in research on corporate finance; Majiameng8918@163.com

Fund Project: The research is sponsored by the Shanghai Pujiang Program (2019PJC054).

DOI : $10.36012 /$ ems. v2i2. 2795

\section{Introduction}

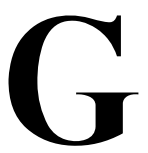

overnment behavior is the key to understand China's economic development and enterprise behavior. The economic growth and financial pressure of local governments have a direct impact on the behavior of enterprises. Therefore, when studying the behavior of enterprises, we must combine it with the action of the government. Tax is an important way for local government to intervene in enterprises. Under the emerging and transitional Chinese capital market, corporate taxation has a brand of political flavor naturally. Although tax laws in different regions are similar, there is often a greater flexibility in the formulation and implementation of tax policies in different areas, which will be directly influenced by the core government officials in the region. 
There are differences between Chinese and American tax systems. The United States implements an independent and parallel system of three levels of federal, weekly, and local taxes. It belongs to a country with a complete tax distribution system. States and localities implement unified federal tax laws and differentiated local tax laws. The tax policy of the United States is revised frequently, but the overall framework changes little. The tax policy modification is greatly affected by political factors, with the republican party inclined to reduce taxes while the Democratic Party inclined to increase taxes. The main tax categories include personal income tax, payroll tax, and enterprise income tax, among which the enterprise income tax accounts for about $9 \%$. China has changed from a planned economy to a market economy. China's current tax system has a total of 18 taxes, value-added tax, corporate income tax, and individual income tax are the top three tax categories in China, among which corporate income tax accounts for about $22 \%$, which has a significant impact on the development of enterprises and the sources of tax collection.

On the other hand, the selection and promotion systems of officials in China and the United States are also quite different. In the United States, officials are generally divided into political officers and affairs officers. Political officers come to power with the coming of a political party. The officers are selected by examination, and the system of appointment is implemented. They are only responsible for the concrete implementation of legal decisions and are not controlled by political parties. In China, officials are selected through examinations and promoted through the ranks, closely related to job performance.

The differences between China and the United States in fiscal and tax systems and official promotion systems bring another perspective to the study of this paper. New economic growth theory and institutional determinism argue that local governments influence the tax burden of enterprises by formulating corresponding tax policies and conducting tax collection, Within the scope allowed by the flexible space. However, most of the previous literature on the influence of the government on corporate tax burden has studied corporate tax $\mathrm{a}^{-}$ voidance from the perspective of tax collection and management, and few pieces of literatures have investigated corporate tax avoidance from the perspective of policymaking and policymakers.

The department of the treasury is the tax policymaker. The department of the treasury shall be responsible for local financial work, organize fiscal revenue according to policies, ensure budgetary expenditure, and promote the development of industrial and agricultural production and various undertakings. Specifically, the office of the treasury, according to the local economic development plan, formulates the annual budget and the final annual accounts and implements the annual budget approved by the local peoplés congress.

Local fiscal policies and annual budgets include annual tax policies and tax targets. The government environment constituted by the local department of the treasury is the key external environment for corporate taxation because the tax policies formulated by the office of the treasury play an important role in the tax burden of enterprises in the jurisdiction.

Government is an empty concept, and its policy features are actually the embodiment of the real core government officials' decision - making. To study the influence and influence path of policy is actually to study the influence and influence path of policymakers. The tax policy of the district department of the treasury is actually the external environment of corporate tax established by the financial leaders within their jurisdiction within the scope allowed by various laws and regulations. Local financial leaders will change due to tenure and other reasons. It is more realistic to view the impact of financial leaders on enterprise tax burden from a dynamic perspective. Moreover, even in the same post of finance director, different preferences of different people will lead to different policy preferences due to the heterogeneity of character characteristics.

So what is the mechanism by which the treasurer affects corporate tax revenue? What are the characteristics of finance directors that have a sig- 
nificant impact on decision - making? To answer the above questions, the research questions of this paper include three aspects: first, does financial leadership influence the tax evasion behavior of enterprises in the jurisdiction? Second, how does financial leadership affect the tax evasion of enterprises in the jurisdiction? Third, what are the characteristics of financial leaders that have a significant impact on decision-making?

To study the above content, this paper manually collected the information of provincial and prefectural finance directors and their backgrounds from 2003 to 2016. Based on the empirical analysis of 21,632 samples, it is found that the individual financial leader has a significant impact on the income tax rate of the company in the region. Further, specific influence paths include the proportion of local general budget revenue in local GDP, the proportion of local general budget expenditure in local GDP, the proportion of local tax revenue in local GDP, and the proportion of local enterprise income tax in all tax revenue. Finally, this paper finds that the financial leadership characteristics that have an impact on corporate income tax are the tenure of the finance director, age, and whether the next position is promoted to deputy governor or deputy mayor. A series of robustness tests also yielded consistent results. Bertrand and Schoar ( 2003 ), Dyreng, Hanlon and Maydew (2010) used them as the research methods.

This paper has the following theoretical contributions. First, this paper is related to the literature on corporate income tax evasion. In the past, most of the relevant literature studied tax evasion from the perspective of internal characteristics and mechanism of enterprises. (Dyreng, Hanlon, Maydew, 2010; Cheng, Huang, Li, Stanfield, 2012 ; McGuire, Omer, Wang, 2012 ; Chyz, Leung, Li, Rui, 2013; Hoi, Wu, Zhang, 2013; Gaertner, 2014; Gallemore, Labro, 2014 ; McGuire, Wang, Wilson, 2014; Armstrong, Blouin, Jagolinzer, Larcker, 2015; Donohoe, 2015 ; Hogan, Noga; 2015; Kubick, Lynch, Mayberry, Omer; 2015) Even in the relatively new literature analyzing corporate tax avoidance from the perspective of external tax environment, it studies corporate tax avoidance from the perspective of tax collection and management. This paper examines for the first time how financial leaders influence corporate income tax avoidance from the perspective of tax policy formulation.

Secondly, this paper is related to the policy uncertainty literature. The uncertainty of various policies will bring uncertainty to the market and cause the fluctuation of enterprise value (Pastor and Pietro, 2011). In recent years, tax policy has become the biggest source of policy uncertainty (Baker etc. ,2016). Media reports have been used in the literature as a measure of policy uncertainty (Gentzkow and Shapiro, 2010; Hoberg and Phillips, 2010; Boudoukh et al., 2013; Alexopoulos and Cohen, 2015). Chen et al. (2016) used the change of party secretary to measure the uncertainty of tax collection and management policies and studied the tax evasion behavior of enterprises. However, none of the above measures of tax policy uncertainty is a direct measure. As the fiscal leader who makes tax policy, its change is the most direct measure of tax policy change.

Finally, this paper is related to the literature on the personal fixation effect of leaders. The classic literature regards corporate leadership as part of the human resource investment of a company but does not distinguish the personality differences of leaders and believes that every leader in the same position will make the same decision (Fama, 1980 ). However, since Bertrand and Schoar (2003), the literature began to consider the influence of the personal characteristics of corporate leadership, namely the fixed effect of leadership, on corporate decision - making (Bamber, Jiang, Wang, 2010; Dyreng, Hanlon, Maydew, 2010; Ge, Matsumoto, Zhang, 2009). This paper, for the first time, expands the analysis of the fixed effect on leaders from the company to the government and discusses the impact of the fixed effect on corporate tax avoidance by the finance minister.

The rest of the paper is arranged as follows. The second part is the theoretical analysis and research hypothesis. The third part is the research design, including sample selection, model construction and descriptive statistics. The fourth 
part is the empirical process and results analysis. Finally comes the research conclusion and enlightenment.

\section{Literature and hypotheses}

Although tax laws are similar in different regions, tax policies are often made to suit officials' own political and business networks. Corporate income tax levels are the result of collusion between the government and business. On the one hand, local governments are also responsible for the supply of public goods, pension, employment, and many other functions. There is great financial pressure, hoping to increase tax revenue. On the other hand, local governments want to retain companies, especially listed ones, to support the region's economic development. In this context, local governments will give enterprises various preferential tax policies to achieve competitive advantages in tax revenue to realize mutual benefit between local governments and enterprises. There is an invisible network between business and government officials, with different companies and officials depending on their proximity. The higher the political connection, the lower the corporate tax rate. Each official has his circle of friends, friends, and friends of their own circle of friends and outside the enterprise is also different. If the core government officials change, the previously stable "political and business ecology" will be destroyed, and the core political and business ties will be broken (An, Chen, Luo, Zhang, 2016).

Different officials have different tax policies, even if they are not catering to their own political and business networks. Officials' achievements are reflected in various economic policies, including tax policies. Treasurer will tailor or tailor local tax policies within the law to stimulate the economy or win hearts and minds and ultimately boost their performance. However, different officials have different performance requirements, different attitudes towards GDP assessment, and various indicators to win the hearts and minds of the people, so they have different starting points for designing policies and ultimately produce different policies.

H1: when other factors remain unchanged, different treasurers have different tax avoidance degrees.

As an important element of regional finance, tax revenue is an important part of regional finance. First, fiscal pressure comes from the imbalance between fiscal revenue supply and fiscal expenditure demand. If fiscal revenue cannot meet fiscal expenditure, budgetary revenue and expenditure gap will be formed. The bigger the budgetary revenue and expenditure gap is, the greater the financial pressure will be. In the late 1980s and early 1990 s, the reform of the tax - sharing system in China opened a prelude, and the implementation of the reform of the tax - sharing system undoubtedly played a positive effect on central finance. The new division of financial and administrative power has raised the ratio of central government revenue to local government revenue to $6: 4$, while local governments bear $70 \%$ of the expenditure responsibility. The apparent mismatch between financial power and administrative power leads to the local financial revenue not making ends meet, which then causes the county and township financial difficulties, land finance, and a series of problems.

Before the reform of the tax-sharing system in 1994 , the proportion of local fiscal revenue was higher than the proportion of fiscal expenditure. The tax sharing reform made the proportion of lo- $^{-}$ cal budgetary revenue drop by $33 \%$ suddenly, but the expenditure responsibility was not correspondingly reduced. After 1994, the proportion of local government revenue began to be smaller than the proportion of government expenditure, and the gap became larger and larger, so did the fiscal pressure (Tang, Mo, Chan, 2017). When central government tax rebates and transfer payments are still unable to make up the gap in revenue and expenditure, local governments must open source their revenue, including budgetary tax revenue and off - budget local debt and other non - tax revenue ( Tang, Mo, Chan, 2017).

In addition to relieving local financial pressure, tax is the main means to realize national financial redistribution, which is of great significance for promoting social equity and justice. The budget work of the department of the treasury includes direct tax (such as individual income tax) 
budget and indirect tax (such as commodity tax, corporate income tax, and other circulation tax) budget. Since all taxes are ultimately passed on to consumers, affecting personal wealth, the fiscal role of redistribution should also be considered in indirect tax budgeting. Wang Hao, LouFeng (2017) found that current our country finance budget lead to the national Gini coefficient rises $2 \%$, among them, the source end of indirect taxes, government spending on social security, and the indirect tax expenditure end make the Gini coefficient rises $1.7 \%, 1.3 \%$ and $3.2 \%$ respectively, the transfer payment and payment of social security and personal income tax make the Gini coefficient drops by $3 \%, 0.4 \%$, and $0.7 \%$ respective1y. At present, the excessive proportion of indirect tax budget in fiscal revenue budget has a negative effect.

H2: fiscal budget is the mediating effect of different financial leaders on the tax avoidance of the enterprises under their jurisdiction.

Corporate income tax levels are the result of collusion between the government and business. On the one hand, local governments are also responsible for the supply of public goods, pension, employment, and many other functions. There is tremendous financial pressure, hoping to increase tax revenue. On the other hand, local governments want to retain companies, especially listed ones, to support the region's economic development. In this context, local governments will give enterprises various preferential tax policies to $\mathrm{a}^{-}$ chieve competitive advantages in tax revenue to realize mutual benefit between local governments and enterprises.

However, in the competition between the two forces, there is a proxy problem between the local finance director and the local leader. Different from the assessment of local leaders focusing on economic development, the assessment of the department of the treasury leaders focuses on ensuring fiscal revenue and improving regional investment and financing efficiency. Therefore, local leaders focus on achieving competitive advantages in taxation through preferential tax policies, while the leaders of the department of the treasury focus on shouldering the supply of local public goods, old-age care, employment, etc. , on ensuring the balance of local revenue and expenditure.

The personal characteristics of the finance leadership will determine the amount of local income tax. These personal characteristics are mainly related to the planning of the finance leadership for the individual's future: the need for promotion and a safe landing. For the financial bureau leaders who have the desire for advancement and expect to go further in their career, they will also have higher requirements on their performance during their tenure. When this requirement is reflected in actual work, it strengthens local fiscal revenue management, including reducing the preferential treatment for corporate income tax (Tang, Mo, Chan, 2017).

Another category that is more concerned with tenure performance is finance leaders who want a safe landing at the end of their tenure. A typical example of a safe landing is the retirement of an officer. Officials will undergo a detailed round of exit audits before they retire to discourage a rush to cash in on their last resort. Since the 18 th $\mathrm{Na}^{-}$ tional Congress of the Communist Party of China (CPC), even after the retirement of officials, if there is any suspicion of corruption, investigation will still be conducted according to the example of unretired officials, which strengthens the strictness of leaders who are about to retire for their final term, and makes the leaders who are about to retire reduce the preferential treatment for corporate income tax.

H3: leaders who have requirements on tenure performance increase the burden of corporate income tax in their jurisdictions.

\section{Research design}

This paper takes all A - share listed companies in China from 2003 to 2016 as the initial samples. Sample selection follows the following basic principles: 1. Exclude listed companies whose trading status is ST/PT in the current year; 2. Excluding financial listed companies. After the above treatment, 21, 632 observations were obtained. We winsorize all of the model's continuous variables at the $1 \%$ level above and below. Information of $\mathrm{fi}^{-}$ 
nancial leadership change was obtained through China fiscal yearbook, and tax - related data and company financial data were obtained from WIND and CSMAR databases.

ETR is the explained variable in this paper, that is, the actual tax rate of enterprises. The effective tax rate is based on current income tax expenses/profits. Besides, CETR is used in this pa- per to measure the effective tax rate considering deferred income tax, CETR $=$ [income tax expense + (delta deferred income tax asset - delta deferred income tax liability) ]/ total profit, ETR and CETR are contracted to $0-1$.

Detailed variable definitions are listed in Table 1.

Table 1 variable definition

\begin{tabular}{|c|c|c|c|}
\hline Type & Variable symbol & Variable name & Variable definition \\
\hline \multirow[b]{2}{*}{$\begin{array}{l}\text { Dependent } \\
\text { Variable }\end{array}$} & etr & Effective tax rate & $\begin{array}{c}\text { Total income tax expense / } \\
\text { pre }- \text { tax earnings before exceptional items }\end{array}$ \\
\hline & cetr & Cash effective tax rate & $\begin{array}{c}\text { (Total income tax expense }+ \text { change of deferred income } \\
\text { tax assets }- \text { change of deferred income tax liabilities) } / \\
\text { pre }- \text { tax earnings before exceptional items }\end{array}$ \\
\hline \multirow{13}{*}{$\begin{array}{l}\text { Control } \\
\text { Variable }\end{array}$} & Roa & Return on assets & Operating income after depreciation / lagged assets \\
\hline & Size & $\begin{array}{l}\text { Natural logarithm of } \\
\text { lagged total assets }\end{array}$ & Ln (lagged total assets) \\
\hline & Lev & Leverage & Total debts / lagged assets \\
\hline & Growth & $\begin{array}{l}\text { Growth rate of } \\
\text { operating revenue }\end{array}$ & $\begin{array}{c}\text { (Operating revenue - lagged operating revenue) } \\
\text { / operating revenue }\end{array}$ \\
\hline & Ppe & Fixed assets scaled by lagged assets & Net PPE / lagged assets \\
\hline & Invent & Inventory scaled by lagged assets & Net inventory / lagged assets \\
\hline & Cash & Cash holding scaled by lagged assets & Cash and short - term investments / lagged assets \\
\hline & Soe & State-owned enterprises & $\begin{array}{l}\text { Code as } 1 \text { if a central or local governmental unit is the } \\
\text { largest direct shareholder(s) or ultimate controlling party }\end{array}$ \\
\hline & Big4 & $\begin{array}{l}\text { Big } 4 \text { accounting } \\
\text { firm as auditor }\end{array}$ & $\begin{array}{c}\text { Coded as } 1 \text { if a firm is audited by a Big } 4 \\
\text { accounting firm, and } 0 \text { otherwise. }\end{array}$ \\
\hline & Inst & $\begin{array}{l}\text { Percentage of shares held } \\
\text { by institutional investors }\end{array}$ & $\begin{array}{l}\text { Number of shares held by institutional } \\
\text { investors / number of total shares outstanding }\end{array}$ \\
\hline & Mgt & $\begin{array}{l}\text { Percentage of shares held by the } \\
\text { firm's management }\end{array}$ & $\begin{array}{l}\text { Number of shares held by directors and managers } \\
\text { / number of total shares outstanding }\end{array}$ \\
\hline & $\operatorname{lngdp}$ & gross regional domestic product & Ln(GDP) \\
\hline & auto & Fiscal autonomy rate & $\begin{array}{l}\text { Provincial general budget revenue } \\
\text { / general budget expenditure }\end{array}$ \\
\hline \multirow{5}{*}{$\begin{array}{l}\text { Intervening } \\
\text { Variable }\end{array}$} & General budget revenue & Percentage of budget revenue & Provincial general budget revenue / GDP \\
\hline & $\begin{array}{l}\text { general budget } \\
\text { expenditure }\end{array}$ & Percentage of budget expenditure & Provincial general budget expenditure / GDP \\
\hline & corporate income tax & Budget enterprise tax proportion & Budget corporate income tax divided by tax revenue \\
\hline & taxgdp & Budget enterprise tax bearing rate & Budget income tax revenue divided by GDP \\
\hline & taxratio & Budget tax bearing rate & Budget tax revenue divided by GDP \\
\hline
\end{tabular}

\section{1 Main regression}

Our primary research question is whether individual treasurer has an impact on corporate tax avoid- ance. Previous literature has mostly assumed that managers are homogeneous and able to provide selfless input into their responsibilities or that 
leaders are heterogeneous but cannot quickly and directly influence them. The opposite view is that fiscal leaders have discretion within a region and use that discretion to affect revenue and possibly

$$
\begin{aligned}
& \text { ETR }_{i, t}=a_{0}+\sum_{k} a_{k} \text { CONTROL }_{i t}^{k}+\sum_{t} a_{t} \text { YEAR }_{t}+\sum_{i} a_{i} \text { FIRM }_{i}+\sum_{m} a_{m} J U_{m}+\varepsilon_{i t} \\
& \text { CETR }_{i, t}=a_{0}+\sum_{k} a_{k} \text { CONTROL }_{i t}^{k}+\sum_{t} a_{t} \text { YEAR }_{t}+\sum_{i} a_{i} \text { FIRM }_{i}+\sum_{m} a_{m} J U_{m}+\varepsilon_{i t}
\end{aligned}
$$

Referring to the practices of Dyreng et al. (2010) and Amstrong et al. (2015), ETR is the effective tax rate of enterprises, which is equal to the enterprise income tax expense divided by the total profit at the end of the previous year. CETR is defined as a company's limited cash tax rate, which is equal to the sum of corporate income tax and deferred income tax divided by the total profit at the end of the previous year. The higher the value of ETR and CETR, the lower the degree of tax avoidance (ETR or CETR, tested separately in regression); YEARt's annual independent indicator variable, $t$ (annual fixed effect); $\mathrm{E}$ is the error term. FIRMi is a separate indicator variable for each company, I (FIRM fixation effect). JUm is a separate indicator for each financial leader, and $\mathrm{m}$ (leadership fixation effect) is the main variable we are interested. In model control, the industry fixation effect controls all the characteristics of the fixed industry, such as the tax avoidance strategies at the level of the industry and the fixed enterprises. The vector CONTROLk of the control variable reflects the fact that these characteristics may change over time and are likely related to tax $\mathrm{a}^{-}$ voidance, which is discussed in more detail below.

If we find that treasurer is important, it may be because they impose different styles on local finance, or it may be that these financial leaders are chosen because of their style. However, due to our control over the effect of enterprises, only with the passage of time, when different styles of financial leaders take office, can our results be attributed to the matching between enterprises and financial leaders. Otherwise, the style of the new financial leadership will be the same as that of the old financial leadership, and its effect will be captured by the enterprise indicator variables. As mentioned earlier, the control in the above equation represents a time-varying corporate-level control vec- tor. In determining the research design, we took into account as much as possible the corporatelevel variables and local, regional economic variables that affect the corporate tax rate.

With this in mind, we chose to include a wide range of variables in the CONTROLK to evaluate our primary analysis. We draw on previous effective tax rate literature (e. g. Mills et al., 1998; Mr. Rego 2003), it is concluded that these variables, including the level of performance, enterprise scale, debt levels, the company growth, tangible capital intensity, intensity, the intensity of monetary fund, the enterprise stock property, if the big four auditing, institutional ownership proportion, dong high ownership control of the company's difference, in addition to use rate of GDP and fiscal autonomy to control the difference of provinces.

Equally important, we control for stable enterprise characteristics by including enterprise fixation effects. For example, if the tax rate of company $\mathrm{A}$ is lower than that of company $\mathrm{B}$ because company A always has more overseas business than company $\mathrm{B}$, then this effect will be reflected in the fixed effect of the company. Similarly, the test control of industry members, because the industry is A fixed enterprise characteristic. However, the change of company A's effective tax rate, if A new financial leader changes company A's tax avoidance behavior, will have A fixed impact on the financial leader. The aim, therefore, is for the executive fixer effect to capture the impact of corporate changes on tax avoidance under his or her direction.

\section{2 Mediating effect : financial budget}

Previous research has found evidence that leaders have different "styles. " We first estimate the equation (1) with various dependent variables except for GAAP ETR and CASH ETR. Based on the 
previous research, we consider the effect of the different regional annual budget, with the following variables, describe each bureau under the leadership of the characteristics of the budget, and as a dependent variable respectively in type (1) regression: general budget revenue accounted for proportion, budget, budget corporate tax accounted for GDP proportion of enterprise income tax and budget, budget, tax revenue accounted for the proportion of GDP definition (see the table 1). Each dependent variable was chosen because it could reasonably represent in advance the type of activity to be undertaken by financial leaders interested in tax avoidance.

We regressed for each variable, such as the proportion of general budget revenue, and controlled for those variables that changed over time, applying a fixed effect of year, industry, and financial leadership. We test whether the coefficients of these fixed effects of financial leadership are related to the coefficients of ETR and CETR in

$$
\begin{aligned}
& \text { ETR }_{i, t}=a_{0}+\sum_{k} a_{k} \text { CONTROL }_{i t}^{k}+\sum_{t} a_{t} \text { YEAR }_{t}+\sum_{i} a_{i} \text { FIRM }_{i}+\sum_{m} a_{m} J U_{m}+\varepsilon_{i t} \\
& \text { CETR }_{i, t}=a_{0}+\sum_{k} a_{k} \text { CONTROL }_{i t}^{k}+\sum_{t} a_{t} \text { YEAR }_{t}+\sum_{i} a_{i} \text { FIRM }_{i}+\sum_{m} a_{m} J U_{m}+\varepsilon_{i t}
\end{aligned}
$$

Previous research has found evidence of predictable differences in management styles among leaders from different backgrounds (Bertrand and Schoar 2003 ). Therefore, we attempted to obtain biographical information (for example, age, educational background, gender) for each financial leader in the sample. We use tenure (Hambrick and D' aveni, 1992; Bantel and Jackson, 1993; Boeker, 1997), age (Carlsson and Karlsson, 1970; Vroom and Pahl,1971; Tihanyi, Ellstrand, Daily and Dalton, 2000), and the next job title to measure the performance requirements and future development of the finance leadership. In addition, we collected information about the educational background of provincial financial leaders, their last job title, and whether they were concurrently the head of the tax bureau during their tenure as an additional test of leadership characteristics. The last position title of the financial leader should reflect whether the leader has been transferred from the financial mouth and whether he has financial management experience. The financial leader's next job title indicates the primary regression discussed earlier. For each pair of coefficients, we estimate the following form of univariate regression model:

$$
\hat{\alpha}_{m}^{Y}=\beta_{0}+\beta_{1} \hat{\alpha}_{m}^{z}+\mu_{m}
$$

where $\mathrm{Y}$ is ETR and CETR, respectively, and $\mathrm{Z}$ is general budget, expenditure, corporate, income tax, taxgdp, taxratio respectively. The specific empirical method is : first of all, explained variable in the model (1) is replaced by the intermediary variables general budget, expenditure, corporate respectively, the control variables are unchanged, to get the treasurer fixed effect coefficients $\hat{\alpha}_{m}^{Z}$. For example, explained variable in model (1) is replaced by general budget and the regression of $\sum_{m} \alpha_{m}$ is $\hat{\alpha}_{m}^{G D}$. Then regress the commissioner fixed effect coefficient from model (1) with the intermediary coefficient from model (2) to capture the coefficient $\beta_{1}$, about which we care.

\section{3 Characteristics : performance requirements}

\section{Empirical results}

\section{1 Main regression}

\begin{tabular}{|c|c|c|}
\hline & ETR & CETR \\
\hline $\begin{array}{c}\text { Fixed effect of } \\
\text { financial leadership }\end{array}$ & $77.50^{* * *}$ & $88.8^{* * *}$ \\
\hline \multirow{2}{*}{ Soe } & 0.005 & -0.0004 \\
\hline & $(1.03)$ & $(-0.08)$ \\
\hline \multirow{2}{*}{ Size } & $0.20^{* * *}$ & $0.030^{* * *}$ \\
\hline & $(9.22)$ & $(6.71)$ \\
\hline \multirow{2}{*}{ Lev } & $-0.018^{* * *}$ & -0.012 \\
\hline & $(-3.81)$ & $(-1.46)$ \\
\hline \multirow{2}{*}{ Roa } & $0.192^{* * *}$ & $0.138^{* * *}$ \\
\hline & $(4.88)$ & $(2.94)$ \\
\hline \multirow{2}{*}{ Ppe } & $-0.026^{* * *}$ & $-0.043^{* * *}$ \\
\hline & $(-4.93)$ & $(-3.31)$ \\
\hline \multirow{2}{*}{ Invent } & $0.068^{* * * *}$ & $0.099^{* * *}$ \\
\hline & $(5.15)$ & $(6.52)$ \\
\hline
\end{tabular}

Table 2 The effect of the fixed effect of treasurer on the effective tax rate of enterprises (ETR\&CETR) 


\begin{tabular}{|c|c|c|}
\hline \multirow{2}{*}{ Cash } & 0.0004 & -0.012 \\
\hline & $(0.13)$ & $(-1.58)$ \\
\hline \multirow{2}{*}{ Growth } & 0.002 & $0.006^{*}$ \\
\hline & (1.09) & (1.78) \\
\hline \multirow{2}{*}{$\mathrm{Mgt}$} & 0.014 & -0.14 \\
\hline & $(0.78)$ & $(-1.02)$ \\
\hline \multirow{2}{*}{ Inst } & $-0.0002^{* * *}$ & $-0.0002^{*}$ \\
\hline & $(-2.76)$ & $(-2.63)$ \\
\hline \multirow{2}{*}{ Big 4} & $-0.160^{* * *}$ & $-0.205^{* * *}$ \\
\hline & $(-6.68)$ & $(-3.30)$ \\
\hline \multirow{2}{*}{$\operatorname{lngdp}$} & -0.031 & -0.011 \\
\hline & $(-1.27)$ & $(-0.23)$ \\
\hline \multirow{2}{*}{ Auto } & $0.085^{* *}$ & $0.110^{* *}$ \\
\hline & $(2.44)$ & $(2.71)$ \\
\hline Year & Control & Control \\
\hline Industry & Control & Control \\
\hline Province & Control & Control \\
\hline $\mathrm{N}$ & 21632 & 21632 \\
\hline $\mathrm{R}^{2}$ & 0.039 & 0.037 \\
\hline
\end{tabular}

Since the situation of each province and each company is different, there may be some missing variables that do not change with time. Therefore, we adopted the fixed - effect model for regression and drew lessons from Driscoll and Kraay's (1998) method of modifying heteroscedasticity (XTSCC). Table 2 reports the estimation results of formula (1) with ETR as the dependent variable and CETR as the dependent variable in the annual sample of companies without tax rate, including the fixed effect, year fixed effect, and industry fixed effect of 88 financial leaders in the sample and controlling time - varying variables (the fixed - effect model randomly deleted a sample, and we collected information of 89 financial leaders in 13 years, so the final test result was 88). The joint significance of all dummy variables of financial leadership is tested below. It can be seen that all of them reach the importance of three stars, proving that the model contains the fixed effect of financial leadership.

After controlling for the influence of other financial leaders, as well as the year and industry influences, these results show that financial leadership has a significant impact on ETR and CETR. This effect occurs after controlling for many of the variables that affect the effective tax rate. This is an important finding in the literature. So far, it has been challenging to find a single factor that determines the effective tax rate. However, in this paper, we record an important factor that has not been considered before - - the individual financial leader has a significant influence on the actual tax rate level of the company in the jurisdiction.

\section{2 Mediating effect : financial budget index}

Table 3 Mediating effect

\begin{tabular}{c|c|c}
\hline intervening variable & ETR & CETR \\
\hline $\begin{array}{c}\text { general budget } \\
\text { revenue }\end{array}$ & $0.513^{* *}$ & $0.532^{* *}$ \\
\cline { 2 - 3 } general budget \\
expenditure & $(2.26)$ & $(2.25)$ \\
\cline { 2 - 3 } corporate & $(5.14)$ & $0.457^{* * *}$ \\
\hline income tax & $0.532^{* * *}$ & $0.688^{* *}$ \\
\cline { 2 - 3 } & $(2.01)$ & $(2.52)$ \\
\hline \multirow{2}{*}{$\begin{array}{c}\text { taxgdp } \\
\text { taxratio }\end{array}$} & $0.00014^{* * *}$ & $0.00013^{* * *}$ \\
\cline { 2 - 3 } & $(3.13)$ & $(2.84)$ \\
\cline { 2 - 3 } & $(3.3)$ & $0.896^{* * *}$ \\
\hline
\end{tabular}

The influence path of financial leaders on corporate tax avoidance is studied from the aspects of general budget revenue and general budget expenditure, the proportion of corporate income tax in tax revenue, tax bearing rate of corporate income tax, and tax bearing rate of tax revenue. Table 3 re- $^{-}$ ports the influence of provincial-level variables as mediating variables on formula (1). We focus on the coefficients and significance of these provincial - level variables on ETR/CETR. It is worth noting that each item in the table is a separate univariate as the coefficient of dependent variable weighted least squares regression. Take the General Budget Revenue (ETR) as an example, we first ETR as formula (1) the dependent variable in the regression, record 88 fiscal leadership individual fixed effect coefficient, again with the budgetary revenues accounted for as a general formula (1) the dependent variable in regression, the same record at this point 88 fiscal leadership individual fixed effect coefficient, using coefficient of two columns of OLS regression. We find that the fixed effect of financial leadership on the effective tax rate is highly positively correlated with the fixed 
effect of senior executives on the mediating variable at the provincial level. That is, the financial leadership influences the income tax burden of the enterprises under its jurisdiction through the for- mulation of the fiscal budget, which verifies hypothesis 2 .

\section{3 Personal characteristics of treasurer: perform- ance requirements}

Table 4 descriptive statistics

\begin{tabular}{|c|c|c|c|c|c|c|c|c|}
\hline Variable name & $\mathrm{N}$ & MEAN & P50 & $\mathrm{SD}$ & MIN & P25 & P75 & MAX \\
\hline last title & 498 & 0.769 & 1 & 0.422 & 0 & 1 & 1 & 1 \\
\hline next title & 499 & 0.236 & 0 & 0.425 & 0 & 0 & 0 & 1 \\
\hline tax chief & 518 & 0.224 & 0 & 0.417 & 0 & 0 & 0 & 1 \\
\hline education & 486 & 3.447 & 4 & 1. 122 & 1 & 2 & 4 & 5 \\
\hline tenure & 518 & 6.525 & 7 & 2. 196 & 1 & 5 & 8 & 12 \\
\hline age & 493 & 52.41 & 53 & 4. 655 & 29 & 50.5 & 55.5 & 58.5 \\
\hline
\end{tabular}

Table 4 gives descriptive statistics of the personal information of financial leaders for whom data are available in the sample. We found that about $77 \%$ of fiscal leadership on a position is financial related, provincial finance leaders don't usually move to different regions, the regional economy has in - depth knowledge, about $23 \%$ of the vice governor is under the leadership of a title or vice mayor, $15 \%$ of financial leadership of party school learning experience, samples is about 6.5 years on average, the promotion to the provincial public finance led an average of 52 years old. When measuring the educational background of financial leaders, due to the extensive time span and the diversity of educational background measurement indicators, We assign a college degree to 1 , a college degree to 2 , a bachelor degree to 3 , a master's degree to 4 , and a doctor's degree to 5 . It can be seen that most provincial financial leaders have obtained master's degrees.

Table 5 The influence of the characteristics of fiscal leadership on the effective tax rate of enterprises (ETR\&CETR)

\begin{tabular}{c|c|c}
\hline Variable name & ETR & CETR \\
\hline \multirow{2}{*}{ last title } & 0.003 & $0.01^{*}$ \\
\cline { 2 - 3 } & $(0.63)$ & $(1.7)$ \\
\hline \multirow{2}{*}{ next title } & $0.011^{* *}$ & $0.11^{* *}$ \\
\cline { 2 - 3 } & $(2.23)$ & $(2.28)$ \\
\hline \multirow{2}{*}{ tax chief } & -0.001 & $0.01^{* *}$ \\
\cline { 2 - 3 } & $(-0.16)$ & $(1.98)$ \\
\hline \multirow{2}{*}{ education } & -0.00002 & $(0.53)$ \\
\cline { 2 - 3 } & $(-0.01)$ & $(001$ \\
\hline
\end{tabular}

\begin{tabular}{c|c|c}
\hline \multirow{2}{*}{ party school } & -0.02 & 0.001 \\
\cline { 2 - 3 } & $(-0.36)$ & $(0.16)$ \\
\hline \multirow{2}{*}{ tenure } & $0.003^{* * *}$ & $0.003^{* * *}$ \\
\cline { 2 - 3 } age & $(3.1)$ & $(3.04)$ \\
\hline \multirow{2}{*}{\begin{tabular}{c}
$*$ \\
\cline { 2 - 3 }
\end{tabular}} & $0.002^{* * *}$ & $0.002^{* * *}$ \\
\cline { 2 - 3 } & $(5.18)$ & $(4.27)$ \\
\hline
\end{tabular}

We manually collected the previous job title and the next job title of each fiscal leader at the provincial level, the concurrent head of the tax bureau, and the financial leaders' educational background, party school training, length of tenure, and average age during their tenure. Table 5 shows the regression results of the fixed effect coefficients obtained from the empirical estimation in formula (1) and the variables that capture the personal characteristics of financial leaders in Table 4. The first column takes the fixed effect coefficient of fiscal leadership in the ETR model of formula (1) as the calculation result of the dependent variable. The second column is the calculation result obtained by using the fixed effect coefficient of fiscal leadership in the CETR model.

We find that the personal characteristics of $\mathrm{fi}^{-}$ nancial leaders partly explain differences in tax avoidance among financial leaders. In our sample, the next position in the financial leadership influenced their tax avoidance. When their next position was deputy governor or deputy mayor, which usually means promotion, the financial leadership was less likely to avoid tax. Other noteworthy variables are the tenure and average age of financial 
leaders. The longer and older the tenure, the higher the effective corporate income tax rate of the provinces and cities under the jurisdiction of financial leaders, which means that they are less likely to avoid tax. If the leader of the treasury office has requirements on performance, the income tax burden of the local enterprise will be increased, which verifies hypothesis 3 .

\section{Conclusion}

This paper uses the data of financial leadership change in Chinese provinces and cities from 2003 to 2016 to investigate the impact of individual financial leaders on corporate tax avoidance in China. The results show that the change of treasurer has a significant impact on the actual tax rate of enterprises, which is another motivation for corporate tax avoidance. In addition, the results of this paper also show that the tenure and the average age of fiscal leaders have a significant impact on tax revenue, and the less tax avoidance fiscal leaders are, the more likely they are to be promoted. It also shows the financial leadership's ability and willingness to influence local tax revenues.

\section{References}

[1] Bertrand, M. , and A. Schoar. 2003. Managing with style: The effect of managers on firm policies. The Quarterly Journal of Economics, 68(4):1169-1208.

[2] Dyreng, S. , M. Hanlon, and E. Maydew. 2008. Long - run corporate tax avoidance. The Accounting Review, 83(1):6182 .

[3] Cheng, C. S. Agnes; Huang, Henry He; Yinghua Li; Stanfield, Jason. 2012. The Effect of Hedge Fund Activism on Corporate Tax Avoidance,87(5):1493-1526.

[4] Mcguire S T, Omer T C, Wang D . 2012. Tax Avoidance: Does Tax-Specific Industry Expertise Make a Difference? Social Science Electronic Publishing, 87(3) :975-1003.

[5] Chyz J A, Ching Leung W S, Zhen Li O, et al. 2013. Labor unions and tax aggressiveness. Journal of Financial Economics, $108(3): 675-698$.

[6] Hoi C K, Wu Q, Zhang H. 2013. Is Corporate Social Responsibility (CSR) Associated with Tax Avoidance? Evidence from Irresponsible CSR Activities. Accounting Review, 88 (6): $2025-2059$.

[7] Gaertner, Fabio B. 2014. CEO After-Tax Compensation Incentives and Corporate Tax Avoidance. Contemporary Accounting Research, 31(4):1077-1102.

[8] Gallemore J, Labro E. 2015. The importance of the internal information environment for tax avoidance. Journal of Accounting and Economics, 60(1):149-167.

[9] Mcguire S T, Wang D, Wilson R J. 2014. Dual Class Ownership and Tax Avoidance[J]. Accounting Review, 89(4):1487 -1516 .

[10 ] Armstrong C S, Blouin J L, Jagolinzer A D, et al. 2015. Corporate Governance, Incentives, and Tax Avoidance. Journal of Accounting and Economics, 60(1):1-17.

[11] Donohoe, Michael P . 2015. Financial Derivatives in Corporate Tax Avoidance: A Conceptual Perspective. Journal of the American Taxation Association, 7(1):37-68.

[12] Hogan B, Noga T. 2015. Auditor-provided tax services and long-term tax avoidance $[\mathrm{J}]$. Review of Accounting and $\mathrm{Fi}^{-}$ nance, $14(3): 285-305$.

[13] Kubick T R, Lynch D, Mayberry M, et al. 2016. The Effects of Regulatory Scrutiny on Tax Avoidance: An Examination of SEC Comment Letters $[\mathrm{J}]$. Social Science Electronic Publishing, 91(6) :1751-1780.

[14] Pastor, L, Pietro, P. 2012. Uncertainty About Government Policy and Stock Prices. Journal of Finance, 67 (4): 1219 -1264 .

[15] Baker T, Cook I R, Mccann E, et al. 2016. Policies on the Move: The Transatlantic Travels of Tax Increment Financing $[\mathrm{J}]$. Annals of the American Association of Geographers, $106(2): 459-469$.

[16] Shapiro G J M. 2010. What Drives Media Slant? Evidence from U. S. Daily Newspapers. Econometrica, $78(1): 35$ -71 .

[17] Hoberg G, Phillips G. 2010. Real and Financial Industry Booms and Busts. The Journal of Finance, 65(1):45-86.

[18] Boudoukh, Jacob, Ronen Feldman, Shimon Kogan, and Matthew Richardson. 2013. Which News Moves Stock Prices? A Textual Analysis. NBER Working Paper 18725.

[19] Alexopoulos, Michelle, and Jon Cohen. 2015. The Power of Print: Uncertainty Shocks, Markets, and the Economy. International Review of Economics and Finance,40: 8 - 28.

[20] Eugene F. Fama. 1980. Agency Problems and the Theory of the Firm. Journal of Political Economy, 88(2):288-307

[21] Bamber L S, Jiang J, Petroni K R, et al. 2010. Comprehensive Income: Who's Afraid of Performance Reporting?. The Accounting Review, 85(1):97-126.

[22] Ge W, Matsumoto D A, Zhang J L. Do CFOs Have Styles of Their Own? An Empirical Investigation of the Effect of Individual CFOs on Financial Reporting Practices $[\mathrm{J}]$. Contemporary Accounting Research, 28(4):1141 - 1179 .

[23] An H, Chen Y, Luo D, et al. 2016. Political uncertainty and corporate investment: Evidence from China $[\mathrm{J}]$. Journal of Corporate Finance, $36: 174-189$.

[24] Tang T, Mo P L L, Chan K H. 2017. Tax Collector or Tax Avoider? An Investigation of Intergovernmental Agency Conflicts[J]. The Accounting Review, 92(2):247-270. 